J. Product. \& Dev., 18(1):77- 84(2013)

\title{
COMPARATIVE STUDIES ON Catharanthus sp. CULTIVARS USING CHLOROPHYLL CONTENT AND PEROXIDASE ISOZYME
}

\author{
Ibrahim A. Ibrahim ${ }^{1}$; Hemeida A. Al. ${ }^{2}$, Amal M.Hussain ${ }^{2}$; Bekhit, M. ${ }^{1}$ and \\ Amal, A. Zweil \\ 1-Plant Biotechnology Department, Genetic Engineering and Biotechnology \\ ,Research Institute (GEBRI), Sadat City, Minufiya University, Egypt. \\ 2-Bioinformatic Department, Genetic Engineering and Biotechnology, \\ Research Institute Minufiya University, Egypt.
}

\section{ABSTRACT}

Three Egyptian Catharanthus cultivars belong to family apocyanaceae \{Roseus, Ocellatus and Albus\} as well as calli were derived from leaf explant for each and grown on MS supplemented with $1 \mathrm{mg} / \mathrm{l} N A A$ and $1 \mathrm{mg} / \mathrm{BA}$, were studied using chlorophyll contents and peroxidase isozyme. According to the contents of chlorophyll $a, b$ and the total chlorophyll, Roseus, and Ocellatus cultivars' chlorophyll contents were more closely related to each other, but distantly related to Albus cultivar. The total chlorophyll contents were 22.86, 22.08 and 30.51 for Roseus and Ocellatus and Albus cultivars, respectively. Peroxidase isozyme study, exhibited five bands in shoots of the three cultivars, Two bands migrated towards the anode (Pex-A1 and Pex-A2) while the other three bands migrated towards the cathode (Pex-C1, Pex-C2 and Pex-C3). Peroxidase isozyme in the callus samples showed the absence of Pex Al and Pex A2 bands in Ocellatus cultivar, and the absence of Pex A1, Pex A2 and Pex $C 3$ in Albus cultivar but not in Roseus one where the all 5 bands were exist.No differences between cultivars were resulted when shoot samples.

Conclusively, it could be concluded that chlorophyll contents and isozyme analysis could be considered as a useful tool for cultivar identification because it is reliable, rapid and can provide identification at some stages in plant life cycle. Isozyme technique can be used to identify the desired genotypes and to exclude the cultivars before establishing; it may also serve to identify the more active cultivar, which is essential for biotechnological programmes.

Keywords: Catharanthus, peroxidase, isozymes, chlorophyll. 


\section{INTRODUCTION}

Morphological characterization is the only official method accepted for registeration and protection of cultivars. However, cultivars can be distinguished not only by their morphological traits, but also by their biochemical, genetic and physiological characteristics (Bailey, 1983 \& Harhash, 2001). Results from gel electrophoresis of isozyme can be useful in estmating population variability and out-crossing rates in horticultural crops (Marquard, 1987 and Harhash, 2001). Isozyme banding patterns frequently are determined to be simply inherited and as genetic markers can confirmation of cultivars, hybrids, and seed purity. The polymorphic isozymes are useful for genotype identification because of their codominant expression and independence from environmental effects. Isozymes also may be useful when detecting the diversity to be preserved in germplasm banks (Lorenzo, 1996 \& Harhash, 2001), particularly in tree crops where physical space is a limiting factor. Isozymes are ideal markers because they are collinear with the gene, commonly codominant in effect and relatively unaffected by the environment (Torres and Bargh, $1980 \&$ Harhash, 2001).

The role of peroxidases in the living plant is not completely understood, although they have been associated with cell wall biosynthesis, response to injury, disease resistance and wound repair. Peroxidases consist of family of isozymes (Prestamo and Manzano, 1993 \& Harhash, 2001) that catalyze the same or similar reactions. All of these enzymes contain identical heme groups but differ in precise composition of the glycoprotein (Gasparet et al., 1982 \& Harhash, 2001).

Therefore, the objective of this study was to differentiate between the three Catharanthus cultivars through isozymes analysis. Also, chlorophyll contents were estimated.

\section{MATERIALS AND METHODS}

\section{Plant materials}

Three Catharanthus cultivars commonly grown in Egypt namely Albus, roseus and ocellatus were used in the present study, callus as well (Figure 1). The seeds were sterilized by sodium hypochlorite for 20 minutes after washing with tab water with surfactant for one hour, then soaked in liquid MS media, when the seedlings are 10- 14 days old, the two cotyledon leaves then were excised, cultured on MS medium supplemented with $1 \mathrm{mg} / \mathrm{l} \mathrm{NAA}+1 \mathrm{mg} / \mathrm{l} \mathrm{BA}$, for callus induction. After 4 weeks calluses are formed. 

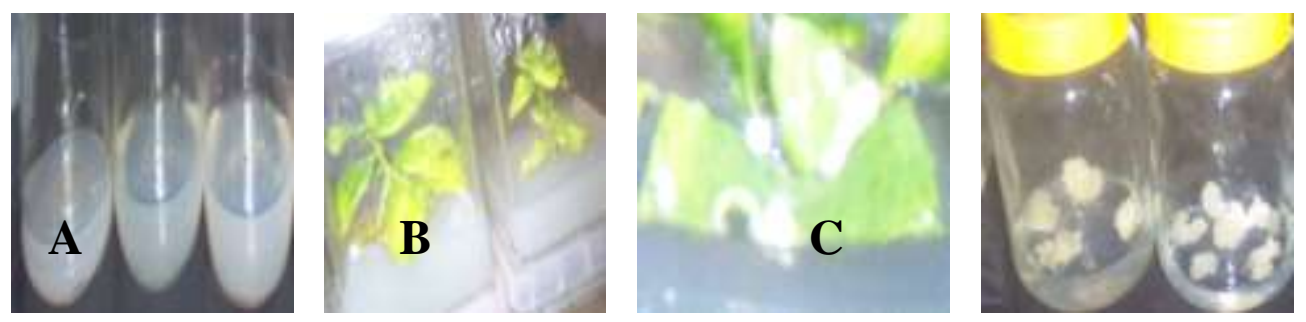

Figure 1: Catharanthus roseus propagation stages. A, B and C correspond to seedling, shoots and callus, respectively.

\section{Chlorophyll contents estimation}

Total chlorophyll content was determined according to (Harborne, 1983). The fresh tissue was ground in a mortar in the presence of excess acetone until all the color is released from the tissue. The brei being washed with fresh acetone until colorless. The extract and washings were then made up to a known volume. Measurement of chlorophylls a and b were made by direct determination of the absorbance using UV-Vis spectrophotometer (Unicam, U.K.). The absorbance was measured at 663 and $646 \mathrm{~nm}$ in $1 \mathrm{~cm}$ cells. The concentrations can then be calculated from the following formulae:

$$
\begin{aligned}
\text { Total chlorophyll }\left(\mathrm{mgl}^{-1}\right) & =17.3 A 646+7.18 \text { A } 663 \\
\text { Chlorophyll a }\left(\mathrm{mg} \mathrm{l}^{-1}\right) & =12.21 \text { A } 663-2.81 \text { A } 646 \\
\text { Chlorophyll b }\left(\mathrm{mg} \mathrm{l}^{-1}\right) & =20.13 \text { A } 646-5.03 \text { A } 663
\end{aligned}
$$

\section{Electrophoretic analysis}

Agar-starch- polyvinylpyrrolidone (PVP) gel electrophoresis was carried out according to the procedure described by Torres and Tisserat (1980) to separate the isozymes.

Extracts were prepared by grinding individual young tissues from all samples of the three tested Catharanthus varieties in cold tris-citric acid buffer $\mathrm{pH}$ 8.3. The homogenate from each variety was absorbed onto a small rectangle (about $4 \mathrm{~mm} \times 2 \mathrm{~mm}$ ) of filter paper (Whatman No.1), The filter paper was placed on the original line of the gels, and after storage at $4{ }^{\circ}$ $\mathrm{C}$ for 30 minutes then removed and the run was started for 90 minutes in response to a constant electric current $(14 \mathrm{~V} / \mathrm{cm})$. Tris-citric acid buffer $\mathrm{pH}$ 8.0 was used as a running buffer. After electrophoresis, gel plates were stained with $100 \mathrm{ml}$ of $0.01 \mathrm{M}$ sodium acetate acetic acid buffer $\mathrm{pH} 5$ containing $0.1 \mathrm{gm}$ benzidine and $0.5 \% \mathrm{H} 2 \mathrm{O} 2$. 


\section{RESULTS AND DISCUSSION}

\section{Determination of chlorophyll contents}

In Albus cultivar, the chlorophyll a and $b$ contents were much higher than that of Roseus, and Ocellatus cultivars (Table 1 and Figure 2). The total chlorophyll contents were 22.86, 22.08 and 30.51 for Roseus and Ocellatus and Albus cultivars, respectively. According to the contents of chlorophyll a and $\mathrm{b}$ and the total chlorophyll.

Roseus and Ocellatus cultivars were more closely related to each other, but distantly related to Albus cultivar.

Table 1. Chlorophyll content of Catharanthus cultivars.

\begin{tabular}{|l|c|c|c|}
\hline \multirow{2}{*}{ Cultivar } & \multirow{2}{*}{ Total chlorophyll } & \multicolumn{2}{c|}{ Molar ratio } \\
\cline { 3 - 4 } & & Chl.( a+b) & Chl.(a/b) \\
\hline Roseus & 22.86 & 22.88 & 0.5 \\
\hline Ocellatus & 22.08 & 23.86 & 0.4 \\
\hline Albus & 30.51 & 30.54 & 1.9 \\
\hline
\end{tabular}

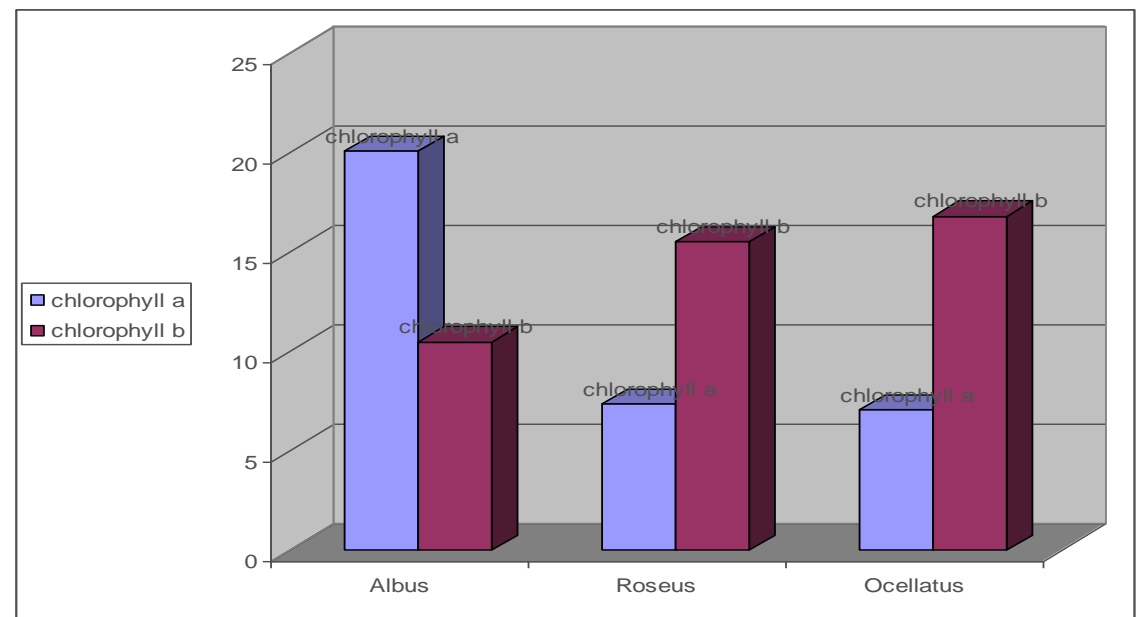

Figure 2. Albus, Roseus and Ocellatus cultivars effect on chlorophyll contents.

\section{Peroxidase isozyme}

The electrophoretic patterns of peroxidase isozymes of Albus, Roseus and Ocellatus cultivars from shoot and callus samples was shown in Figure $3 \mathrm{a}$ and $\mathrm{b}$. Differences in the activity level of peroxidase isozymes were found to be as follow: Five bands of peroxidases were found in the 

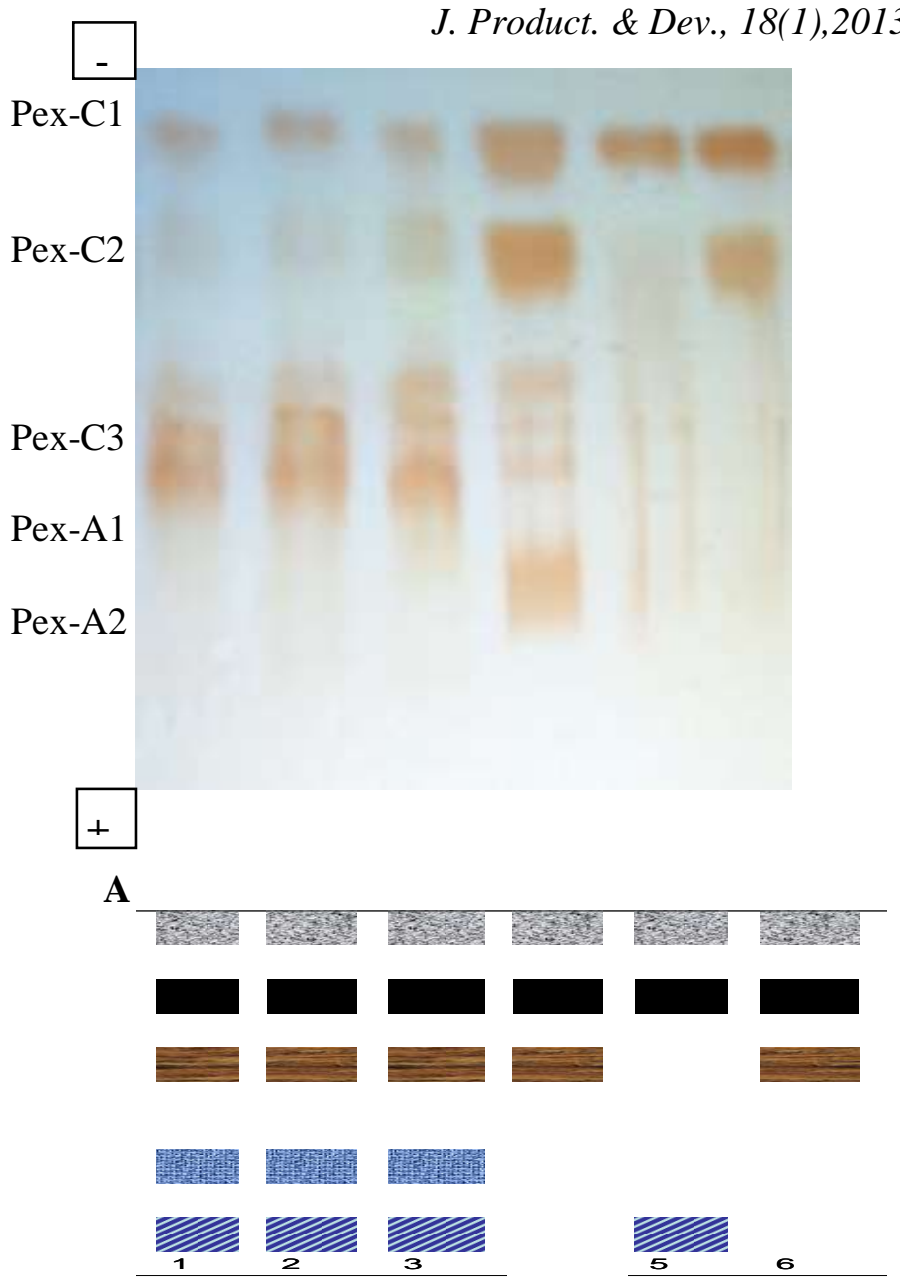

B

Figure 3. Zymogram (A) and Ideogram (B) of peroxidase isozyme patterns in the Catharanthus cultivars Roseus (lane 1,4), Ocellatus (lane 2, 5) and Albus (lane 3,6) from shoot and callus samples (lanes1-3 and 4-6, respectively).

shoots of the three cultivars (Figure $3 \mathrm{a}$ and $\mathrm{b}$ lanes 1-3). The anodecally migrating bands were designated as Pex-Al and Pex-A2 according to their mobility, where Pex-A2 is faster than Pex- A1 in its migration towards the positive pole. The cathodically migrating bands were designated as $\mathrm{Pex}-\mathrm{C} 1$, Pex-C2 and Pex-C3. Two bands migrated towards the anode (Pex-A1 and Pex-A2) while the other three bands migrated towards the cathode (Pex-C1, Pex-C2 and Pex-C3). Peroxidase isozyme of the callus samples resulted in the absence of Pex A1 and Pex A2 bands in Ocellatus cultivar and Pex A1, Pex A2 and pex C3 bands in Albus cultivar but not in Roseus cultivar. 
The isozyme pattern of various enzymes has been used as a valid and well documented technique for the identification of cultivars of various plant species, such as the date palm (i.e. Torres and Tisserat, 1980; Baaziz et al., 1994; Baaziz, 1989 and El-Hadrami and Baaziz, 1995); avocado (Torres et al., 1978a); strawberry (Bringhurst et al., 1981) and grape (Wolfe, 1976).

In the present work, the present studied the difference between Catharanthus cultivars using chlorophyll contents and peroxidase isozyme. According to the contents of chlorophyll a, b and the total chlorophyll, Roseus, and Ocellatus cultivars were more closely related to each other, but distantly related to Albus cultivar. Also, Peroxidase isozyme of the callus samples resulted in the absence of Pex A1 and Pex A2 bands in Ocellatus cultivar and Pex A1, Pex A2 and Pex C3 bands in Albus cultivar but not in Roseus cultivar. No differences between cultivars were resulted when shoot samples were used.

Conclusively, it could be concluded that chlorophyll contents and isozyme analysis could be considered as a useful tool for cultivar identification because it is reliable, rapid and can provide identification at some stages in plant life cycle. Isozyme technique can be used to identify the desired genotypes and to exclude the cultivars before establishing; it may also serve to identify the more active cultivar, which is essential for biotechnological programmes.

\section{REFERENCES}

Baaziz M (1989). The activity and preliminary characterization of peroxidases in leaves of cultivars of date palm (Phoenix dactylifera L.). New-Phytologist., 111 (3): 403-411.

Baaziz, M. Aissam, F.; Brakerz, Z.; Bendiab, K.; El-Hadrami, I. , Cheikh, R. (1994). Electrophoretic patterns of soluble proteins and active isoforms of peroxidase and polyphenoloxidase typifying calli and somatic embryos of two reputed date palm cultivars in Morocco. Euphytia, 76 (3): 159-168.

Bailey, D.C.(1983). Isozymic variation and plant breeders' righs, 425-440. in Tanksley , S. D. and orton T.J.(eds). Isozymes in plant genetics and breeding. Part B. Elsevier, Amsterdam.

Bringhursh, R.S.; Arulserkar, S.; Hancock, V.F. and Voth, V. (1981). Electrophoretic characterization of strawberry cultivars. J. Amer. Soc. Hort. Sci., 106 (5): 684-687. 
El- Hadrami, I. and Baaziz, M. (1995). Somatic embryogenesis and analysis of peroxidases in Phoenix dactylifera L. Biologia Plantarum, 37(2): 197-203.

Gasparet, T.C.; Thorpe, T. and Greppin, H. (1982). A survey of their biochemical and physiological roles in higher plants. Universite de Geneve, centre de Botanque, 889-1112.

Harborne, A. J. (1983). Phytochemical Methods. A Guide to Modern techniques of Plant Analysis, $229 \mathrm{pp}$.

Harhash, M. M.; A.S. Khaled and A.A. Hemeida (2001). Genetical and environmental effects on date palm peroxidase isozyme banding patterns of some soft date palm cultivars. Adv. Agric. Res., 6 (2): 231-237.

Lorenzo, S.; Fernfindez, J. and Moreno, J.(1996). Variability and grouping of northwestern spanish chestnut cultivars.II.Isoenzyme Traits. Journal of Soc. Hort. Sci., 121(2):190-197.

Marquard, D. R. (1987). Isozyme, inheritance, polymorphism and stability of malate dehydrogenase and phosphoglucose isomerase in pecan. Journal of Amer. Soc. Hort. Sci., 112(4):717-721.

Prestamo, G. and Manzano, P. (1993). Peroxidase of selected fruits and vegetables and the possible use of ascorbic acid as an antioxidant. Hort. Science, 28 (1): 48-50.

Torres, A. M. and Tisserat, B. (1980). Leaf isozymes as genetic markers in date palm. Amer. J. Bot., 67 (2): 162-167.

Torres, A.M. ; Diedenhofen, U.; Bargh, B. O. and Knight, R. I. (1978a). Enzyme polymorphism: a genetic marker in the avocado. Amer. Journal of Bot., 65(2): 134 -139.

Wolfe, W.H. (1976). Identification of grape varieties by isozyme banding patterns. Am. Journal of Viticult., 272: 68-73. 


\section{دراسة مقارنة بين أصناف الونكا المصرية باستخدام محتوى الكلوروفيل و كذلك المشابهات الانزيمية لانزيم البيروكسيديز بالئيز}

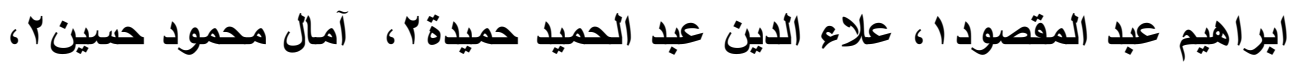

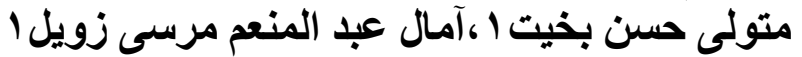

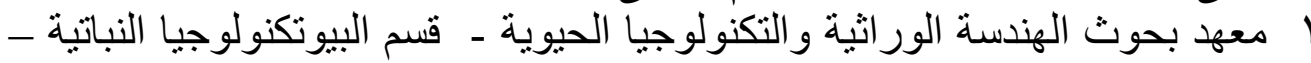

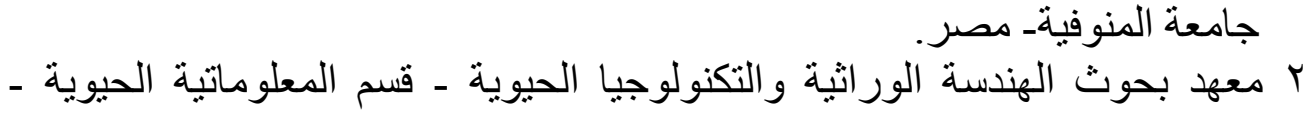

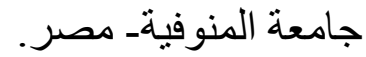

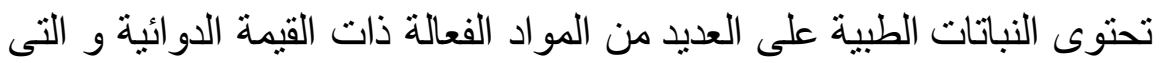

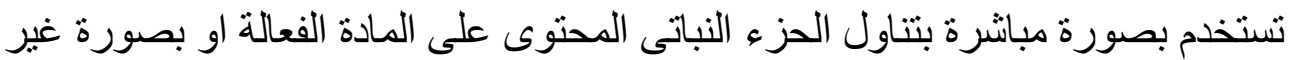

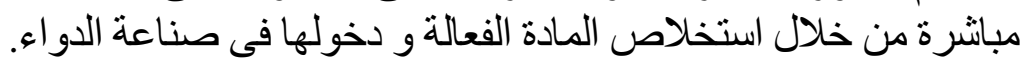

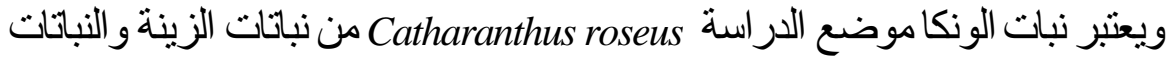

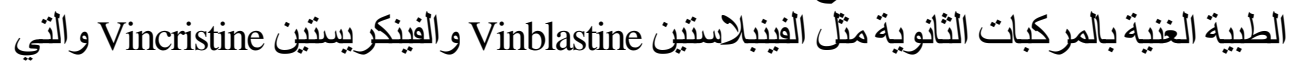

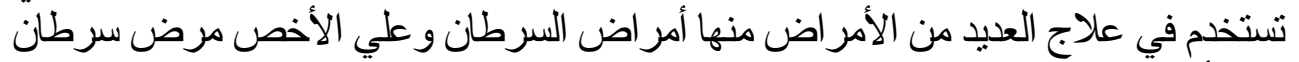

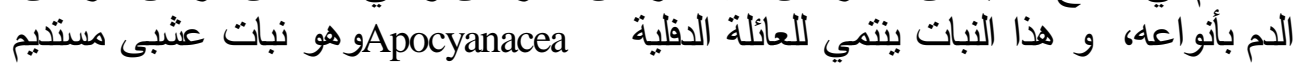
الخضرة (معدر صيفى) يزرع فى معظم الوطن العربى كنبات زينة نظر الجمال الجمال ازهات هارة و

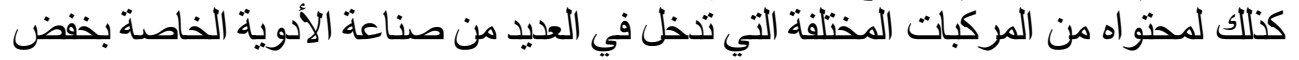

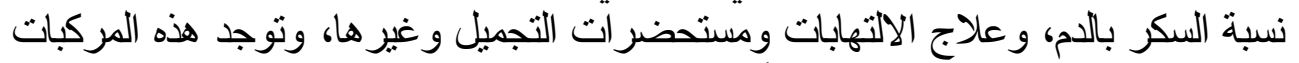

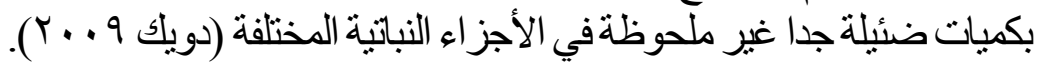

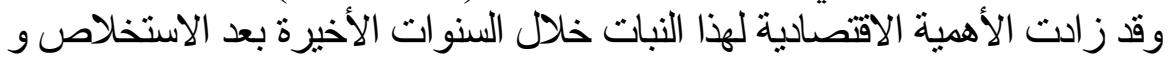

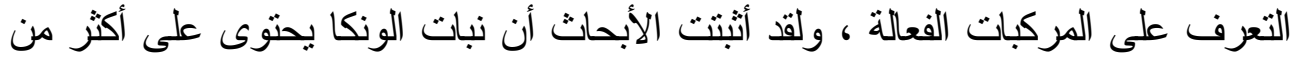

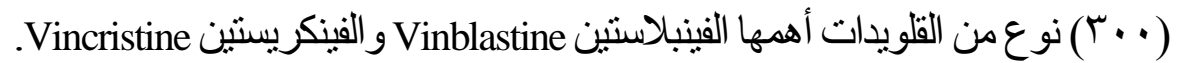

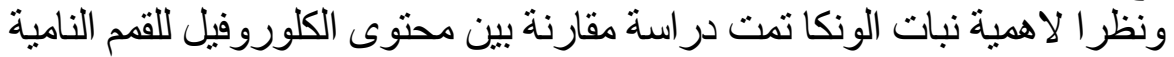

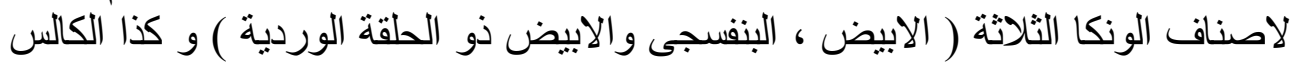

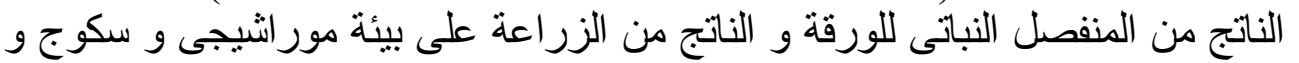

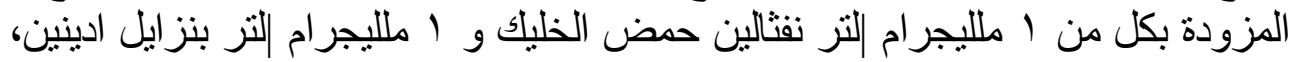

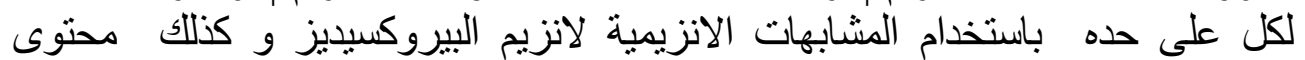

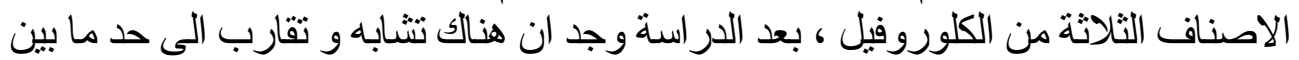

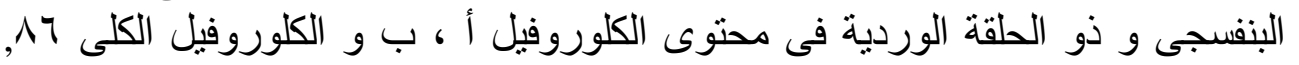

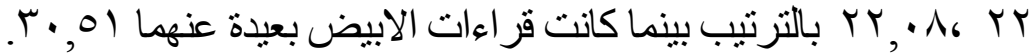

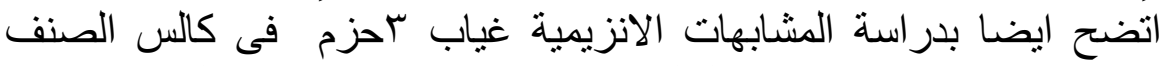

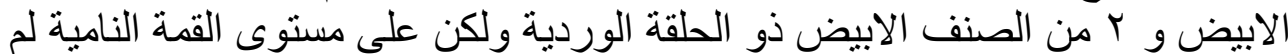
يوجد اي غياب لاع من الحزم الخمس. 